\title{
Highgate Cemetery
}

A City of Angels

Natalie Fritz

1. An Angelic Little Girl. Or Starting an Emotional Walk through Highgate

«The Angels wished a pretty flower to lay at Jesus's feet/they picked from the little ones a lily pure and sweet/our little child was chosen, and now she rests in peace.» This bittersweet poem is engraved on a tombstone erected on a grave for a three year old girl (fig. 1).

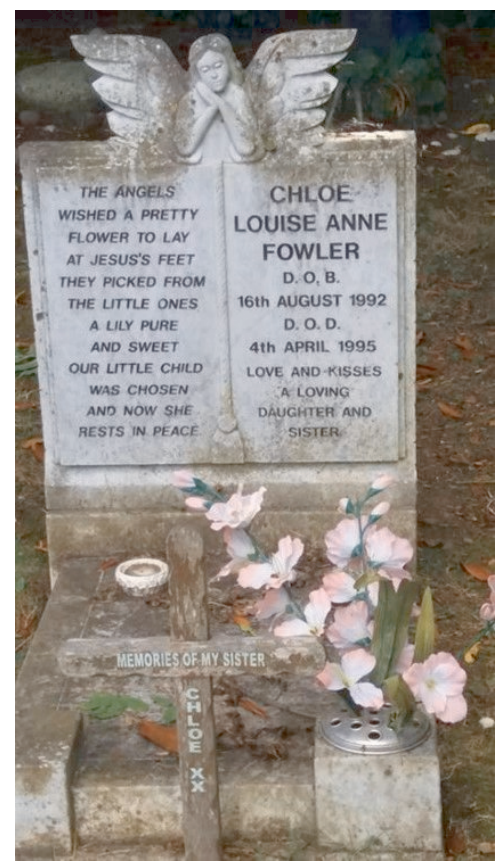

Fig. 1: The melancholic angel: The tomb of Chloe Louise Anne Fowler, a three year old girl, in the Eastern part of Highgate Cemetery, London (Image: Natalie Fritz 2016). 
Above the weathered marble stone an angel figure looks down with a melancholic facial expression, her head resting on her folded hands, as she watches over the deceased child. Looking at this monument of mourning, one feels touched. Grief at the death of a child is universal, affecting everyone in every era. Yet here, in this particular example, the composition of poem and sculptured angel evokes a specific idea of how this particular family tried to overcome their little girl's death and tried to remember her; and this insight into the intimate process of mourning touches one deeply. The fact that her family emblematized the girl as a lily, taken by the angels to praise Jesus, indicates on a first level, that the remaining family members tried to cope with their loss by integrating the death of the beloved child into a greater and more meaningful concept, a religious world view. ${ }^{1}$ Imagining their own daughter or sister living a «new life in heaven, near God, can be a comforting act.

On a second level, the visible monument of loss, the tombstone with its composition of poem and carved angel functions as an instruction for the visitors as to how the family wants the deceased to be remembered: as an innocent girl, who was so pure and sweet that not even the angels could resist her. The emotional impact of the engraved poem increases in combination with the representation of the melancholic angel and vice versa. This tombstone can be found in the Eastern part of London's Highgate Cemetery, the part of the graveyard that is open to the public without booking a guided-tour. If you are walking through the cemetery as a tourist, a visitor or a mourner, you may pass this particular gravestone and the way it is composed may influence your vision of the once living girl. The perception of this tombstone is - of course - individual, as every meaning making process varies according to beholder, time, place, socioreligious context and so on, but the arrangement of the monument limits the range of possible interpretations. In the first instance, the beholder could interpret the angel simply as a guardian or keeper of the little girl's memory, watching from above over the physical remains, reminding visitors of her and, more generally, of human finitude. One could also interpret this human and female looking figure as a (prospective) representation of the little girl that has become an angel herself and watches, although with a melancholic touch, her family from above. In this sense, the

1 On religious world views and their potential for creating sense and orientation see Stolz 2001; Geertz 1987; Pezzoli-Olgiati 2008, 45-66. 
angel as a mediator between heaven and earth ${ }^{2}$ may simultaneously personify a transcendent being as well as the human deceased, who is no longer physically present, but is now visually a heavenly resident. This interpretation of the angel as surrogate for the girl could be strengthened by referring to the poem, which is a derivate of a popular memorial prayer, that says: "God needed an angel in Heaven to stand at the Saviour's feet./His choice must be the rarest. A lily pure and sweet./He gazed upon the mighty throng. Then stopped and picked the best./Our child was His chosen one with Jesus (he's/she's) now at rest.» ${ }^{3}$ The gravestone poem's definition of an angel relates to the practice of transferring (angelic qualities $^{4}$ like high virtues or beauty to human beings, usually to underline their exceptional character in an affectionate and admiring context. ${ }^{5}$

To conclude this thought, one could say that the particular representation was probably made according to an order placed by the deceased's parents. It shows the deceased girl as her grieving relatives wanted her to be remembered. The representation produced by the composition of poem and angelic figure functions on the one hand as an instruction on how to remember the dear child: Chloe was "pure» - a quality which marks a pious being - and therefore was metaphorically taken ‘home by other angels. On the other hand the mourning monument can be considered a memory 'written in stone, a physical archive and is therefore also a part of the cultural history that illustrates how mourning, loss and death are represented in public spaces of remembrance in a specific time and space.

This paper aims to stimulate readers and prospective Highgate visitors to think about the ways our perception of an artefact - in this case, a tomb or mourning monument decorated with an angel - is affected by its particular visual design. Following an approach that draws upon phenomeno-

2 Many different functions were and are attributed to angels. In the following paragraph we will explore their main functions in a short overview. For further information see Schmidt/Schmidt 2007; Krauss 2005; Jones 2010.

3 The poem seems to be very popular and can be found in diverse funeral card catalogues and on funeral parlour's homepages, for example: http://www.funeralhelper .org/bereavement-child-announcement-verses.html; https://www.memorialstatione ry.com.au/funeral-wordings-Poems-for-Baby-Children.html (accessed January 27, 2019).

4 «The personalisation of good (and evil) powers is a self-evident practice in the New Testament as it also was in its Jewish context. Through the representation of angels the pious of the Bible illustrates the secret of God's deeds" (Böcher 1982, 599, translation by the author).

5 On the use of the word angel, see a standard dictionary definition: https://en.oxfo rddictionaries.com/definition/angel (accessed October 10, 2018). 
logical and anthropological image theories, we try to describe the representation's possible effects on the beholder as an interaction between artefact and human body. ${ }^{6}$ In the context of the cemetery, a place of emotionally charged remembrance practices, the question arises: how do aesthetic aspects shape the way we remember? In this paper we will explore some of the angel figures that ornament the graves of Highgate Cemetery and take a closer look at the possible impact their particular representations may have had and continue to have on the beholder and the beholder's way of remembering the (un)known deceased. The sample of angel figures chosen are representative rather than exhaustive, with a slight emphasis upon less well-documented examples. As a consequence particularly well known examples, such as the memorial for Ada Beer in the Beer Mausoleum, an artefact that has been investigated extensively in previous studies, will not be considered in this paper. ${ }^{7}$ The paper tries to encourage readers to think about the interaction between artefact, memory and beholder and therefore it seems to be more promising to look at less popular representations for further investigation, as the reader's prior knowledge of such artefacts is likely to be less developed. Thus, the paper is interested in questions of visual artefacts and their long lasting affective quality. This paper will therefore particularly concern itself with memory: the connection between collective and individual memory and how they interact with and relate to material culture.

Memorials have a distinctive purpose of guiding the beholder's view in a particular direction, to indicate a particular way in which someone or an event should be remembered. This aspect of memorial culture can be exemplified very well by considering the angel figures of Highgate Cemetery. Depending upon what function the specific angel figure was designed to fulfil, the aesthetic realisation was adapted accordingly. All angel figures represent, on a socio-historical level, specific religious concepts of the afterlife and memory culture. On a more individual level they also represent so-

6 For phenomenological approaches to <images (here the term is used following Hans Belting in a broad sense which includes virtual, material and mental images) which explain the practice of looking at an artefact as an experience of entering bodily into a discourse with the represented, see Bredekamp 2010; Boehm 2007; Boehm 1994; Didi-Huberman 2000; Didi-Huberman 1999. For the definition of <image used here see Belting 2001.

7 More information about the Beer Mausoleum can be found at: http://www.mmtru st.org.uk/mausolea/view/229/Beer_Mausoleum; https://www.srf.ch/kultur/gesellsch aft-religion/die-traurige-geschichte-einer-familie-die-geschichte-schrieb (accessed October 24, 2018). 
cial status and power and are therefore enduring images of a particular practice of commemoration. The memorial (the term indicates its very purpose) helps us to remember someone or an event in a clearly confined way, one could call it a «canonised retrospection〉. As a consequence, the act of remembrance can be characterised as a process that goes backwards and forwards at the same time because we revitalise past events or dead persons in our memory. ${ }^{8}$ The memorial, tombstone or mourning monument in this sense resumes the function of a visible and material connection between the different time periods of past, present and future. Standing now in front of a tombstone - in a way - we think backwards, but, at the same time, the memorial has a prospective function because it is erected for ongoing generations. The crucial questions are: why do people ornament the graves of their beloved ones with angels? What impact do the specific representations have on our understanding of the deceased, the time they lived in and the relation between material culture and processes of remembrance, and the relation between individual and society?

To approach these questions, it seems useful to start with a short summary of iconographic types of angels and their meaning. Afterwards we will reflect on memory processes and try to understand how these processes are connected to material culture. To conclude these considerations, we will describe selected angel figures in Highgate Cemetery in a thick way, as Clifford Geertz would say. ${ }^{9}$ In this way we will try to understand how the angel-figures function as material memory and how their representations instruct us how to read them. As a consequence we will also try to understand what they reveal about the society they were created for and about the heirs of these images', today's society.

\section{Are They Feathered like Eagles? Or a Very Short Introduction to Angel Iconography}

Highgate Cemetery is literally a city of angels: there is an enormous quantity of different angel figures populating the area. Every single one is con-

8 See Kierkegaard 2000, 3-4.

9 American anthropologist and ethnologist Clifford Geertz elaborated the term «thick description`, which he understood, drawing upon Gilbert Ryle's insights in the field of linguistic philosophy, as a hermeneutics of culture. In «The Interpretation of Cultures: Selected Essays», his essay collection of 1973, Geertz pleads for a context-based interpretation that involves the level of production, distribution and reception. Geertz 1987. 
nected to a specific remembrance strategy and visually communicates a

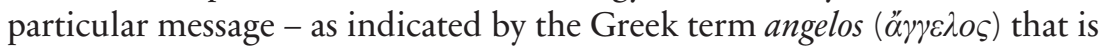
used in the Septuagint, as a translation equivalent of the Hebrew term mal'a $\underline{k}$ which means emessenger.${ }^{10}$ Angels are thus convenient religious symbols that - depending on one's view point - offer differing meanings. As an attentive visitor, one becomes aware that every single angel type evokes a particular reaction, both cognitive and emotional. But why did and do people use angels as symbols on mourning monuments?

We find angels in the Old and the New Testament as well as in some Jewish and Christian Apocrypha and in patristic writings. In numerous accounts of the Old Testament and in the Apocrypha angels are described as heavenly creatures, who act as God's servants, as God's instruments to communicate with human beings. They are referred to as «sons of God» (Job 1:6) or the "host of heaven» (1 Kings, 22:19), characterisations that highlight their spatial and emotional> proximity to God. ${ }^{11}$ Only three of this multitude of heavenly servants are named in the Old Testament or its Apocrypha: Michael (Dan 10:13), Gabriel (Dan 8:16) and Raphael (Tob $5: 18$ ). But the existence of heavenly servants became ever more appealing in the New Testament period, such that these three archangels became surrounded by a huge quantity of other angels with specific abilities and duties. The patristic literature of the early Christian church - in authors such as Pseudo-Dionysius the Areopagite's De caelesti hierarchia ${ }^{12}$ - developed a hierarchical scheme, to structure the angel population according to their functions. The iconography of these early Christian angels remains fairly consistent until the end of the $4^{\text {th }}$ century AD: male figures, wearing a white tunic and without wings. ${ }^{13}$ They are easily distinguishable from extra-Christian goddesses like the Greek Nike or other winged spirits like the

10 See «Engel» in Kluge 2011. The Septuagint is an ancient Greek version (translation) of the Hebrew Bible/Old Testament.

11 See Schmidt/Schmidt 1981, 127.

12 The author of several theological-philosophical treatises, who, around 500 AD, depicted the celestial hierarchy, and who wrote under the pseudonym of «Dionysius the Areopagite», the $1^{\text {st }}$ century AD Athenian convert of St Paul (see Acts 17:34), (therefore also called «Pseudo-Dionysius the Areopagite»). Full text in English translation by John Parker from 1897 is available online: https:/en.wikisource.org /wiki/Dionysius_the_Areopagite,_Works/On_the_Heavenly_Hierarchy (accessed July 1, 2017). For a more recently published translation see Pseudo-Dyonisus 1987, 143-191.

13 «Their appearance resembles humans (Acts 12:15) particularly white clothed and illuminated males (Mk 16:5 par.; Jn 20:12, Acts 1:10)» (Böcher 1982, 596, translation by the author). 
Roman Genii. Based on the idea that celestial beings need to have wings, representations from the early $5^{\text {th }}$ century onwards tend to depict winged, male angels. Until the Middle Ages this way of depicting angels remains the standard artistic convention (fig. 2).

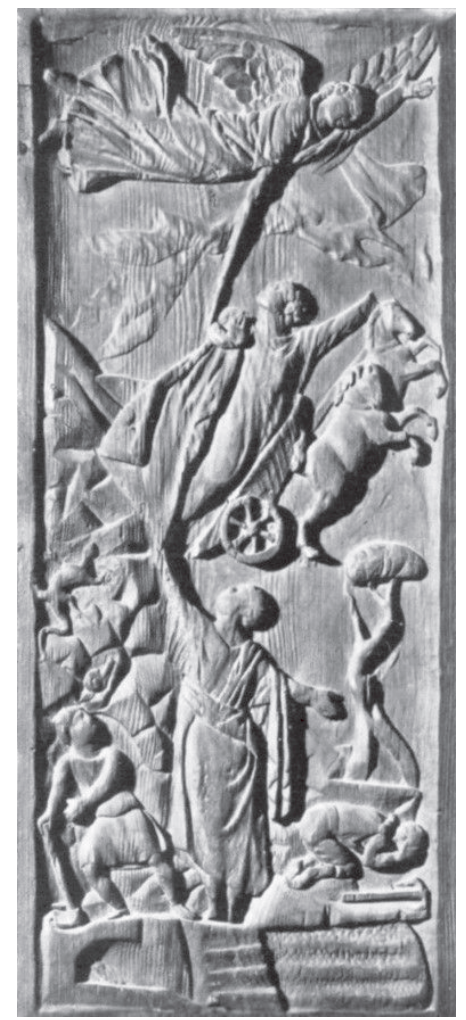

Fig. 2: Rome, S. Sabina, relief on wooden door, right side, about 430 AD: Ascension of Elijab: Elisha grasps the coat of the prophet (C) University of Bologna/Fondazione Federico Zeri - Fototeca Zeri, Università di Bologna, inv. 2953).

A notable contextual aspect of this type of angel is that these male representations have often been used - and continue to be used - to illustrate apocalyptic narratives: we encounter them as the $\operatorname{good}\rangle$ - or even more accurately - the «angelic soldiers» in stories of the eternal conflict against the evil forces (Rev 12:7-9); as the ones responsible for weighing the soul's balance> (Dan 5:27); or as escorts of the deceased humans' souls (Lk 16:22). 
According to these particular functions, representations of such male angels are frequently integrated in religious architecture: they decorate the tympana of church entrances, supporting pillars or cemetery chapels and appear also as sculptures on fonts. All these representations remind the beholder to follow the right path, to believe in God, and behave like a Christian in order to gain admission to heaven at the end of days.

During the Middle Ages the representations of angels became more flexible and elaborated and new iconographies emerged, notably, the female angel on the one hand and the child-like angel or putto (cherub) on the other. ${ }^{14}$ Representations of angels changed partly due to alterations in the practices of Marian adoration and worship. In the Middle Ages the human side of Mary, as opposed to the former distant and incomprehensible 〈Theotokos», the «mother of God` or «God-bearer, became more important - even though she remained the most special one amongst other women as QQueen of Heaven'. Artists showed her in contexts which were recognised as typically female and adapted her as a role model for the good housewife, ${ }^{15}$ mother or leader. Presenting Mary as the QQueen of Heaven' the artists surrounded her - like human queens and noblewomen - with female servants and maids. Mary's celestial household became populated with female angels of a soft and beautiful appearance. These female angels impacted on the iconography that continues to inform today's representations - especially popular depictions (fig. 3) often shaped by Victorian archetypes. ${ }^{16}$

This popular type of angel is no longer awe-inspiring with a slightly violent, even martial trait, but softer with a more emotional impact as Nina Auerbach explains: «Our present revulsion against angels as anything more than smirking inhabitants of Christmas trees may take inspiration from Victorian England, whose prevailing popular angelology cast angels as irrefutably female and by definition domestic, rather than as the striding

14 See Schmidt/Schmidt 1981, 134-137.

15 Interestingly, angels will subsequently become synonyms for the good housewife and her pious behaviour in the early Victorian period - women and angels will now become <domesticized and idealised at the same time. See Brown 2001, 58.

16 «Even though the iconography shows that angels are of androgynous appearance until the $15^{\text {th }}$ Century, Victorian artists link angels and womanhood visibly and allegorically in terms of an idealization of the efficient and obeying wife or wifeto-be. This connection was, on a social level, very useful to reinforce paternalistic hierarchy» (De Girolami Cheney 1992, 243-244); «In the Victorian era the artistic topic of angels was literally everywhere on postcards, in poetry, on wallpapers and on cemeteries» (Garrett 2015, 60). 


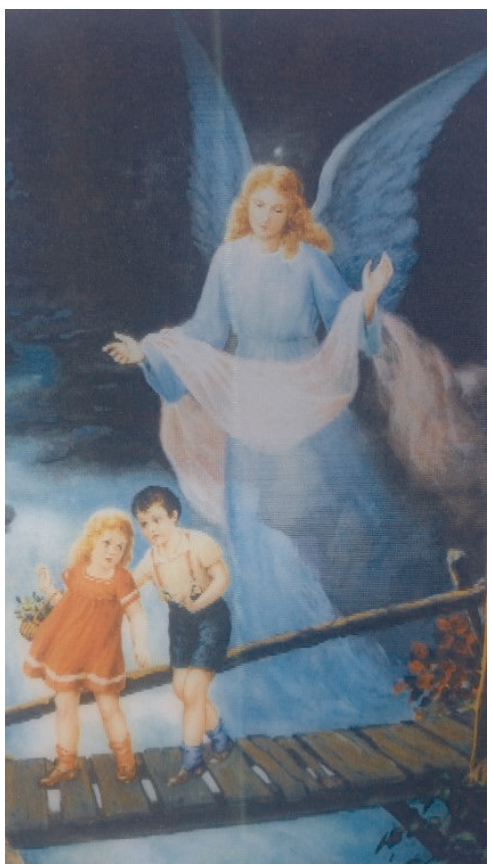

Fig. 3: Kitsch: A postcard with a guardian angel watching over two small children crossing a wild river, EGIM srl Milano, Italy (Image: Natalie Fritz).

martial and potentially bisexual males they had been.» ${ }^{17}$ Therefore these female angels are often used to illustrate moments of the strongest emotions, greatest joy and most intense pain. We see these angels in various portraits of the deposition from the cross or supporting the dead Christ (so called angel pietà). ${ }^{18}$ But they also praise, often gathered in groups, the expectant mother or sing for the new born child. As so called «soul bearers) angels appear on Italian tombstones and mourning monuments in the $13^{\text {th }}$ century. ${ }^{19}$ As - in this sense - guardian angels, they watch over humans (Mt. 18:10) and assist them actively to avoid trespassing the law and live a good life. In the $14^{\text {th }}$ century they also become guides or escorts of deceased persons - a development of the soul bearer role that transforms the function

17 Auerbach, 1982, 64.; see also Schmidt/Schmidt 1981, 135.

18 See Osten 2017 (1960), 601-621; http://www.rdklabor.de/w/?oldid=93200 (accessed July 13, 2017).

19 See Mendelssohn, 2012 (1907), 79. 
of the guardian angel for the living into a continuing service that guides the deceased into the transcendent sphere of a specific afterlife..$^{20}$

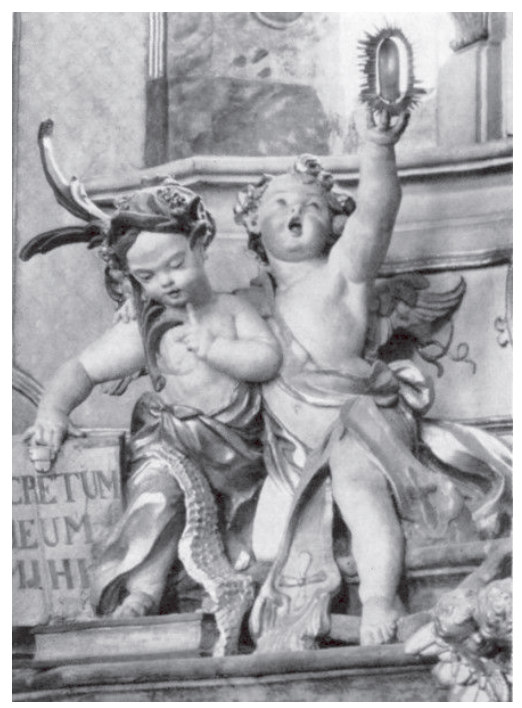

Fig. 4: Klosterkirche Osterhofen: Putto (Cherub) with attributes of the Saint John of Nepomuk (RDK V, 473, Abb. 86. E. Q. Asam, 1732, Photo: O. Poss, Regensburg, AS 4824).

A little later, in the $15^{\text {th }}$ century small, delicate and bird-like angels appear in Northern Europe (fig. 4). Because of their height and their delicate facial features, they were supposed to be child-angels. In Southern Europe, the putto (cherub) became popular at the same time. These angels are also small but often naked and well nurtured. They are playful and mirror the naive joy for life and innocence of human infants (fig. 5).

Edward Burne-Jones (1833-1898) was one of the most influential artists of the Victorian era, especially with regard to the design of angels. Many of Highgate's angels date from this era. He felt himself drawn to the immaterial and described his response to his context as follows: «the more materialistic Science becomes, the more angels shall I paint.» ${ }^{21}$ Lutchmansingh explains that in Burne-Jones's artistic work «fantasy and imagination, in a symbolic mode, create a sense of enchantment, as the medium of an eman-

20 See Mendelssohn, 2012 (1907), 78.

21 Lutchmansingh 1989, 123. 


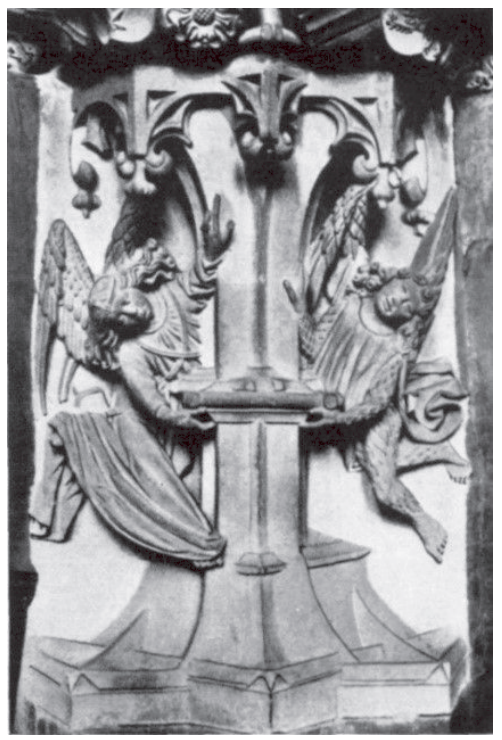

Fig. 5: Gernsbach (Baden), last third of 15th century: Angel at the house of sacraments; the angels are feathered (@ RDK Labor).

cipatory potential, and generate the utopian hope of recovering the unities lost in the process of rationalist fragmentation and reconstruction of the subject under capitalism.» ${ }^{22}$ Gregg Garrett adds: «Iconographically influenced by the art of the Middle Ages and the Renaissance they [the angels] embodied now Victorian piety in a specific way: Burne-Jones represented them as «dignified, stately, powerful, useful.»²3 Garrett explains that Burne-Jones' particular way of representing angels in various situations and functions made them a popular motif for a variety of different media and times: "And impressively the artist showed these beings in their various functions as guardian angels, archangels and so on. Burne-Jones's angels are not limited to the Victorian era but had an impact on the representation of these beings until the times after World War I.» ${ }^{24}$

Although the abundance of angel types in art is tremendous and we have only been able to touch the surface in this overview, nonetheless, we have been able to recognise some thematic and artistic analogies that link

22 Lutchmansingh, 1989, 124-125.

23 Garrett 2015, 61.

24 Garrett 2015, 62. 
all the different representations. Angels are not only regarded as messengers but also as active mediators (for example, as guardian angels) between heaven and earth, between the transcendent and the terrestrial sphere. They are, so to say, a perfect symbol for liminality on a temporal, spatial and a religious or ideological level. ${ }^{25}$ Angels are not bound to our understanding of time; they are timeless because they are not human. We can find their representations made of marble or another stone in Highgate but they do not belong to the human sphere. As liminal beings between immanence and transcendence, they fight side by side with God against evil forces whilst simultaneously assisting humans in living a good life according to the commandments and finally guiding them to heaven. The eschatological and apocalyptic sceneries the angel figures appear in produce ideal motifs for mourning monuments that highlight either reassuring (fighting against the evil), comforting (admission into heaven) or emotional (angel as «substitutional> mourner) aspects. ${ }^{26}$ Depending on what memory of the beloved deceased person(s) the bereaved wanted to emphasise with the mourning monument or gravestone, they chose a specific iconographic tradition and allowed stheir angel to be shaped in accordance with that motif. The angel figure then works on several levels as a material memory of the dead person(s): as a substitute for the deceased (figs. 1; 6; 7 ), because the dead person was angelic in the eyes of the grieving family; as a substitute for or addition to the mourners (figs. 9; 10), who are, as the angel shows, permanently grieving; as a monument of or a reference to a distinctive belief/a religious worldview (figs. $11 ; 8$ ); as a means to communicate extreme emotions (fig. 8). This huge spectrum of functions is possible because by looking at these human-shaped figures we fill them with emotions - even though we know that they are not as we are. But standing in front of an anthropomorphic body or looking at a human-shaped face showing a specific emotion it is easy to associate with the feeling shown because we as humans express emotion in a similar way. As material repre-

25 The term liminality is shaped by Scottish anthropologist Victor Turner whose thoughts are based on Arnold van Gennep's work on the rites of passage (Les rites de passage). Liminality defines the liminal status the participants of a ritual go through when they 〈leave〉 the 〈past status and before they attain a «new〉 status. It is an ambiguous period, that serves to establish a new identity within a larger group of fellow men. See Gennep 2004; Turner 1995.

26 See RDK, Engel und Menschen (angel and humans), Engel als Pfleger und Bewacher des Grabes (angel as keeper and guardian of the tomb), trauernde Engel (mourning angel), http://www.rdklabor.de/wiki/Engel\#C._Engel_und_Menschen. 2C_Engel_als_Pfleger_und_Bewacher_des_Grabes.2C_trauernde_Engel (accessed July 12, 2017). 
sentations of beings in between the spheres, angels transmit in a very explicit way - as every cimage does to varying degrees - the inherent difference between presence and absence. ${ }^{27}$ Maybe because of this specific quality, the angel representations sometimes function as stylised substitutes for the deceased persons or the bereaved, as Bredekamp explains in his Image Act Theory. ${ }^{28}$ There he explains that the substitutive image-act depicts the exchangeability of image and body in situations where images are treated like humans (for example, in the adoration of Saints).

The following examinations of selected angel representations are based on a catalogue of over 100 photographs of angels taken by the author or her colleagues whilst visiting Highgate Cemetery. All of the representations analysed in this paper share the characteristic wings and female features prominent in the Victorian era and were selected to give an overview of recurrent types amongst the immense range of angel iconography in sepulchral art.

\section{The Recumbent Angel. An Individualised Representation of Loss and Hope in a Public Sphere}

In our consideration of the range of angel iconographies and their use as grave adornments two key aspects have emerged so far: first, angel figures are liminal beings mediating between the temporal and the heavenly spheres and therefore may be used both as surrogates for the deceased and as a comforting symbol of a specific idea of the afterlife. Second, angels who function as mourning monuments mirror the deceased's status both within the family and within society.

A fascinating example can be found on the tomb of Mary Nichols in the Eastern Part of Highgate Cemetery (figs. 6 and 7). On a marble bed of realistic length lies an angel figure who is the height of an average woman.

27 Concerning the topic of presence and absence within the study of images see Belting 2005; Belting 2001; also Boehm 2007, 33-55; Boehm 2010, 243-267; Waldenfels 1990, 204-224 and Bredekamp 2010.

28 See Bredekamp 2010. 


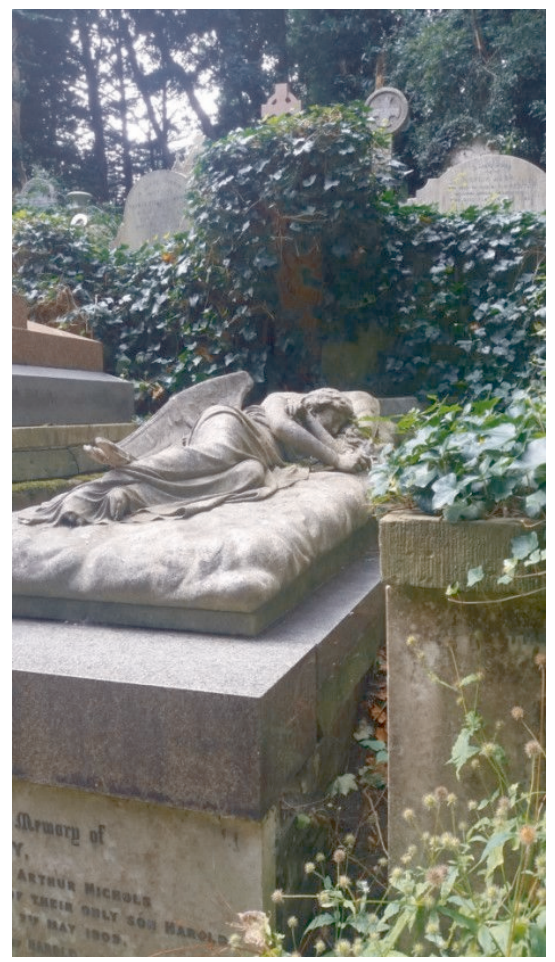

Fig. 6: The recumbent angel on the bed. Highgate East Cemetery (Image: Natalie Fritz 2016).

The angel's features are soft and feminine and her eyes are closed. Her hair is spread on the cushion and her facial expression is relaxed. The tomb was commissioned by Mary's husband and their only son. The epitaph says: «The darling wife of Arthur Nichols and fondly loved mother of their only son Harold, who fell asleep $7^{\text {th }}$ May 1909.» (fig. 7).

We do not know, if "fell asleep» is just a euphemism (even though it seems obvious given the time in which it was made) for «died or if she really died in her sleep but the combination of representation and inscription is highly emotional. The tomb transmits at the same time the greatest loss and the deepest affection - even though we see no mourning or grieving angel here. With reference to Kierkegaard one might say that while observing this grave one revitalises or gets back one's own experiences of loss and grief and adds a new insight that finally transfers those experiences in- 


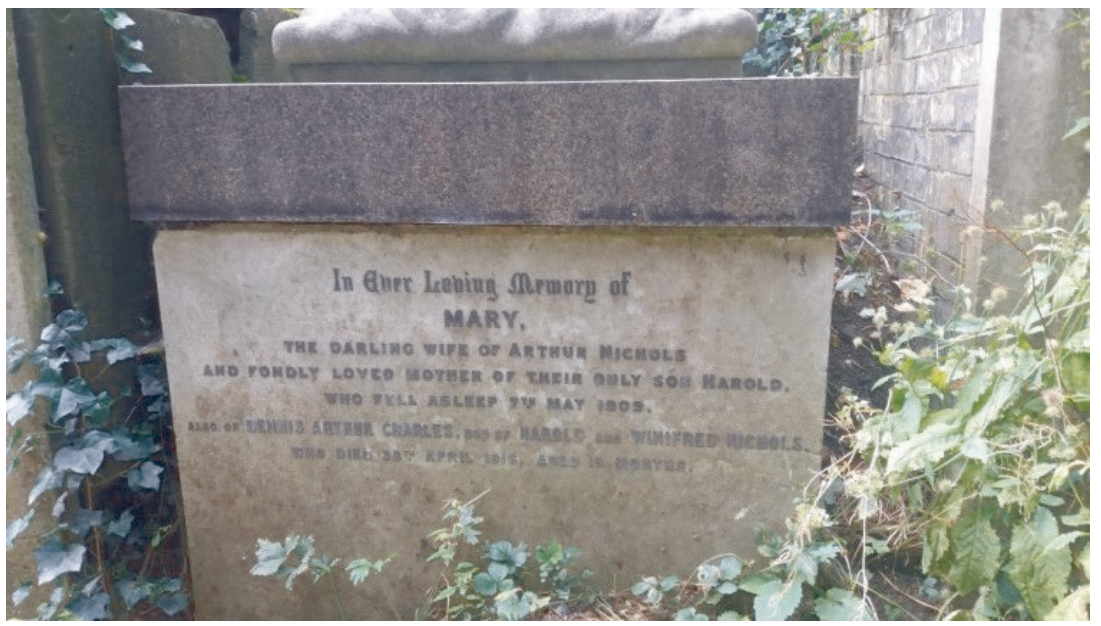

Fig. 7: The epitaph on Mary Nichols' grave. Highgate East Cemetery (Image: Natalie Fritz 2016).

to a prospective state, which is of a higher potency than before. ${ }^{29}$ The beholder thus has paradoxically enriched or increased his or her own reality by reflecting upon it by considering a monument of a past time. With Kierkegaard one might say that due to the actual reflection of experiences the whole remembrance process moves the beholder into a quasi-transcendent sphere because it enables him or her to catch a glimpse of what eternity might mean. ${ }^{30}$

Also the setting is very special due to the recumbent angel figure on the bed which invites the visitor to interpret this representation as the deceased - especially in view of the epitaph. As we noted earlier, in the Victorian period the term angel was often used to describe the ideal woman, occupying herself with her family's needs and the household. ${ }^{31}$ Against this background it seems sensible to interpret the angel on Mary Nichols' tomb as an idealisation of the deceased as well as a reference to her specific social status in a patriarchal society. As visitors we do not know if the deceased woman looked like the angel figure on the bed, but that is not the crucial point. What is important is the setting and the way the whole image is composed. There are no other angel figures in either part of High-

29 See Kierkegaard 2000, 109-115.

30 See Kierkegaard 2000, 123-130.

31 See Auerbach 1982, 64.

https://doi.org/10.5771/9783845294520-273, am 26.04.2023, 12:55:44 
gate - or at least none you will pass on the official tour - who are shaped in the same way as Mary Nichols' angel. The artist used a popular symbol of the Christian faith and put it in a slightly different light to recap the words of the epitaph and make the deceased unique. In this sense, this mourning monument is a very elaborate artefact because it plays with polysemy on several levels. On one level it shows a popular practice of transcending human beings - mostly in retrospect - by adapting specific characteristics of supernatural beings, to depict the deceased as an angel. This strategy works out on a social level by displaying to others the deceased's moral qualities. ${ }^{32}$ And on an individual level, one may feel comforted, because by looking at the winged figure one may imagine her living an afterlife amongst other angels. On the other hand, the idea of changing an established mourning symbol slightly, reinforces its particularity, and thus anchors the image deeply in the visitor's memory. Following Aleida Assmann we could state that in this case, even though the representation of the angel figure is more personalised than in other examples, it's not so much the deceased that becomes essential, but the way her memory is "written or sculptured in stone». ${ }^{33}$ We could say that this example shows how the bereaved ordered a specific representation of a beloved person, that thus becomes public and then becomes a part of an individual imaginary - that of the beholder's - again. The innovative transformation of popular symbols provokes surprise, de-familiarizing the familiar, and therefore endures in our memory - a desirable quality for a mourning monument or tombstone. ${ }^{34}$

\section{Angels and Repetition. Liminal Figures between Past, Present and Future}

As we have noticed by analysing the recumbent angel figure, the bereaved try to keep the memory of the dead person alive by building an adequate material «memento in the cemetery which must be - so to say - ritually visited. Aleida Assmann calls this ritualised way of commemoration

32 See Footnotes 14, 15, 16.

33 «One remembers what appeared to be striking, what left a mark, what was felt meaningful» (Assmann 2006a, 2). http://www.bpb.de/system/files/pdf/0FW1JZ.pd $\mathrm{f}$ (accessed November 10, 2018, translation by the author).

34 For the interrelation between power and aesthetic conventions and the effect of their violations see Schade/Wenk 2011, 121-125; Fritz 2018, 73-75; Frank/Lange 2010, 47-52; Berek 2009, 87-94. 
«pietas». 35 The function of this practice is to demonstrate respect for the deceased person and to maintain the connection to a past that is fundamental to the individual's identity construction. Thus, this procedure is not only a practice for the honour of the dead but also serves as a technique of selfvalidation. The monument's dimensions, the material, the style, and the location within the cemetery all display the social and economic status of the deceased and his or her family. ${ }^{36}$ The realisation of the specific grave is in this sense not only a posthumous fame, but also a future-oriented reference to the deceased person's descendants. Danish philosopher and theologian, Søren Kierkegaard, stated that remembering and repeating is the same movement in opposite directions: the process of remembering is repeating backwards whereas the actual repetition is the process of remembering forwards. ${ }^{37}$ Remembering in this sense «brings back» ${ }^{38}$ the power of the past due to the process of fetching it with the present's vitality and transfers this power into a future perspective. So, one could say that the act of repeating is an act of fetching something from the past and transferring it to the present and thereby revitalising it time and time again. Repeating is always connected with the process of remembrance - at least on a subconscious level - but does not remain in the past but links it with the present. Repeating therefore doesn't mean that a thing has been performed already several times, but the process of repeating adds something new to it. ${ }^{39}$

Repeating a specific kind of representation and adapting it to the current social conventions is also a revitalisation of the past by transforming it into a present state. Innovation happens by adapting a tradition to the ac-

35 Assmann 2010, 33.

36 Aleida Assmann calls this kind of self-immortalisation «fama» and distinguishes the latter from «pietas» because for the fama the work and behaviour of the deceased during his or her life is relevant. His or her achievements can only be made public to a greater group but it's a form of self-staging as Assmann describes it. Assmann 2010, 33; 36-38.

37 «Wiederholung und Erinnerung sind die gleiche Bewegung, nur in entgegengesetzter Richtung; denn dasjenige, woran man sich erinnert, ist gewesen, wird rückwärts wiederholt, während die eigentliche Wiederholung eine Erinnerung in vorwärtiger Richtung ist» (Kirkegaard 2000, 3).

38 The Danish term «gentage» and the German term «wiederholen» both mean repeating and get back.

39 «Die Dialektik der Wiederholung ist leicht; denn das, was wiederholt wird, ist gewesen, sonst könnte es nicht wiederholt werden, aber gerade, dass es gewesen ist macht die Wiederholung zu etwas Neuem» (Kierkegaard, 2000, 22). 
tual circumstances, the actual context. ${ }^{40}$ If we have a closer look at an angel figure on a more recent grave in the Eastern part of the cemetery we will understand how Kierkegaard's thesis of repeating can also function on an aesthetic level: by adapting a specific iconography to a new context (fig. 8) the artist transfers the past - as a repetition of a specific visual strategy in combination with individual and collective commemoration processes into the present and in this sense «makes eternity visible».

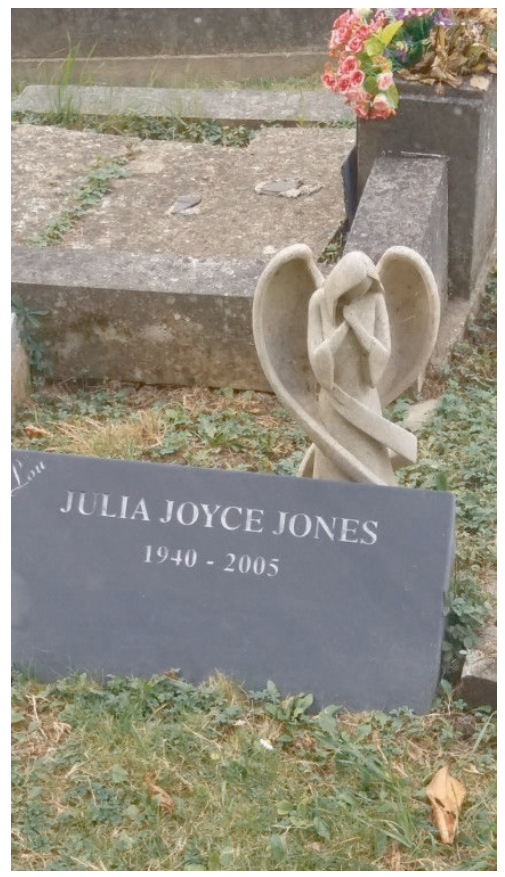

Fig. 8: A small white marble angel stands behind a black marble memorial plaque. Highgate East Cemetery (Image: Natalie Fritz 2016).

The angel stands behind the gravestone. The gravestone stands in the foreground, and is as important as the lines engraved on it. Made of black marble and even though it is a small gravestone - compared to the older graves - lying directly on the earth, it attracts one's attention. It is shaped in a simple but classy way. The black marble is rectangular, like a plaque and

40 See Chapter 10 about images «travelling through space and time» in: Fritz/ Höpflinger/Knauss/Mäder/Pezzoli-Olgiati 2018, 193-214. 
engraved on it are just the name of the deceased woman, her birth date and the date of her death as well as the name of the bereaved person, who presumably gave the order to create the mourning monument in this design. The person, who no longer lives, remains the centre of attention. The angel is surely not an impersonation of the deceased, it is not naturalistic but slightly abstract. The angel is quarried of white marble, very simple and elegant. It is small but highly affecting because the angel has her hands folded on her chest right under the chin, a gesture we often see in Western paintings, engravings even films, and which signals a shocking pain. Even though we cannot see tears one imagines them while decoding the gesture. The wings of the angel are slightly open and entangle the body of the angel figure. There is a comforting sign that visually highlights the love the bereaved person felt for the deceased: the folded wings form a heart shape. In this sense, one could assume that the angel figure is a substitute for the bereaved who mourns intensely.

Even though this tombstone with its specific angel figure was erected around one century later than the previous example, it is obvious that it too adapts particular gestures of human behaviour in a contemporary artistic style, which have been transmitted by different media and remain part of our collective imaginary until today. In this sense this example shows that to revitalise or evoke feelings an angel figure on a grave need not be huge in scale, but simply touch us by representing the feelings that are usually linked to loss and death. Referring to Aby Warburg's so-called Pathos Formula, which highlights the effect of repeating specific visual tropes that are emotionally charged and thus work as cultural engrams, memory traces of past experiences that are part of our cultural knowledge, whose affective power functions in different contexts and times, these engrams evoke particular feelings in the beholder. These feelings are not bound to a specific time but are just human and can be classified, understood and adapted because they are still part of our shared human knowledge. ${ }^{41}$

On the other hand, this example highlights how tradition and innovation determine and shape each other and how this permanent process influences the collective and the individual memory, which is constantly altered by new adaptations of «former new images». ${ }^{42}$ The «old» images are

41 For more information on Warburg's fascinating work consider Wuttke 1998; Gombrich 1992; Diers 2009.

42 «Former new images» is a term created by Hans Belting to show how images are transmitted «using» different media as a sort of carrier. «All old images are former new images. Some images appear to be new because they use different media or 
reused and, in this sense, are revitalised. They belong as much to the past as to the present and the future.

Accordingly, this new aspect may change the outcome of the repeated action and may therefore inherit a future related potential. Following Kierkegaard's thesis, one could depict the function of a specifically shaped mourning monument as a possibility for the self-staging of the living: they direct a glance at the past whilst visiting the cemetery. If the deceased person was for instance a mother and her grave is adorned by an angel escorting the dead mum into heaven, the beholder concludes that she was a good person and that her children - at least some of them - are good persons, too.

\section{Angel Representations on Tombstones. Visual Archives of Past Beliefs and Persons}

This leads us to the question of how individual memory correlates with collective memory and how the private correlates with the public sphere while visiting angel-decorated tombs in Highgate Cemetery. As we have already stated the mourning monument is not a private artefact, merely for the family members' contemplation, but, because it stands in a public place, it is also for public viewing. And the public, the majority of whom lack any acquaintance with the deceased person, need instruction on how the deceased should be remembered. The specific angel shape resumes this task by communicating visually a particular way of remembering the known or unknown dead. The individual memory becomes a collective one because at least some aspects that are ascribed to the deceased person are transformed into a material memorial and thus become part of a collective image reservoir. And this seems a perfectly logical strategy concerning memory, if we assume, that «people live within images and understand the world through images ${ }^{43}$ and therefore the practices of remembrance must

react to new practices of perception» (Belting 2001, 54-55, translation by the author).

43 Art historian Hans Belting thinks that with a wide definition of «image that includes material, virtual and mental images, it becomes clear that our world is a world built of images. We, as individuals, permanently internalise external images produced by other members of the society, which become our images, because we save them in our physical memory and then adjust new images referring to the repertoire we possess and which is collective. See Belting 1990, 9. 
be a process of recalling (images), that are linked to specific persons, emotions, places or events.

Around 1920 French sociologist Maurice Halbwachs described how individual and collective memory are linked. ${ }^{44}$ The individual is indeed the subject of memory and remembrance - but he or she remembers in a cadre sociale, in a social frame. The individual thus has a memory that consists partly of his or her own memories and partly of the memories of the society. These latter memories are historical because the individual has not experienced them directly, but earlier generations of the society he or she is part of. And - to come back to the «world of images» - because the individual is socialised within a specific society that is built and legitimised by specific images he or she internalises the images that are important to the society he or she lives in. Hans Belting says that our collective predisposition and our individual condition amalgamate whenever we use images for orientation because we don't know where the «me» begins and the «other» ends. ${ }^{45}$ The society establishes itself through repeating important images and building up a tradition or a canon. But the image repertoire can change with new generations, changes of power or with the use of new technologies. Halbwachs states that an individual and a society are only able to remember past persons and events that can be reconstructed meaningfully in the specific social frame of the reality they live in. ${ }^{46}$ If no one is left anymore to narrate the story of the event or to tell stories about the deceased, one is hardly capable of recreating images of the past. In this case the memory just vanishes. Egyptologist Jan Assmann highlights that certain memories may vanish, memories that are part of a communicatives memory which refers to a recent past and are mostly orally transmitted. ${ }^{47}$ If these memories are not saved in any way, they vanish when the last witness of the event dies. A «cultural memory by contrast, is fixed to a particular moment in the past, which is of particular importance to that society. ${ }^{48}$ «Cultural» memory transforms historical facts into myths and different societies work out specific techniques to transmit these constitutive events, essential rules and important personalities: they elaborate «canons» of fun-

44 See Halbwachs 1997.

45 «Unsere kollektive Veranlagung wirkt mit der individuellen nahtlos zusammen, wann immer wir uns an Bildern (genauso wie in Bildern) orientieren, ohne dass wir wissen, wo die eine anfängt und die andere aufhört.» (Belting 1998, 36-37, italic as in the original text).

46 See Halbwachs 1997, 390.

47 See Assmann 1992, 50-52.

48 See Assmann 1992, 52-54. 
damental narratives that are transmitted by diverse means of communication, either orally, ritually, in another performative manner or through art. In this text we subsume under the term <images the transmission and performance of such fundamental narratives, because every story - even if it is just told once - evokes images in the audience, mental images, which are transmitted and at the same time saved for later generations. But, these diverse techniques of keeping the past present do not all work in the same way. Aleida Assmann, states, that there are two ways of understanding memory: $\langle a r s\rangle$ is the way of saving or recording a specific something in a specific moment like when we write a diary or save a copy of a document on a computer or in a virtual cloud. ${ }^{49}$ We try to freeze the particular moment in a form that guarantees an absolute conformity between input and output even years or centuries later. Here we remember events, rules, persons based on accurately documented «standard narratives〉. Maintaining the conformity means maintaining the canon. Interestingly, we do not necessarily need devices for this process of saving, even though we often use pens and paper, a recorder or a camera. Our brain is also perfectly capable of memorizing something like a poem or the lyrics of a song. ${ }^{50}$

The other way of understanding memory Assmann calls $\langle$ vis». This is the act of remembering - or not. The process of remembering starts in the present and tries to work back mentally to past events. ${ }^{51}$ There is no absolute conformity between what was and what is now remembered, if remembered at all. Many memories fade away because they are not essential for the stability of the group any longer. In this sense, history is what individuals in a society remembered and transmitted. But, to highlight the important character of specific events or personalities which legitimize the actual rulers of a society, they try to influence and shape the memory of the collective by realising monuments, public spaces like museums and libraries that mirror a certain perspective on the past. An «official memory develops. ${ }^{52}$ This memory serves to underline the identity of a group, consisting of different individuals who feel associated with it. Thus, the act of shaping a collective memory has according to Assmann three reasons: legitimation, as explained already, delegitimization - if alternative forces assume power - and distinction. The last one serves to strengthen the bond between individual and society by declaring what is us and what belongs

49 See Assmann 2010, 28.

50 See Assmann 2010, 28.

51 See Assmann 2010, 29-30.

52 See Assmann 2010, 138. 
to us. Through memory, we realise, we become who we are. We construct our identity by integrating it into a temporal and social context which legitimises our existence and provides us with the required orientation. ${ }^{53}$

All angel representations work as an archive of a specific belief, a specific orientation that still has a certain impact on our present life, but some of them refer to explicit concepts which may not be known anymore. As an example let us look at an «angel holding a cross» representation we find on several tombs in Highgate Cemetery.

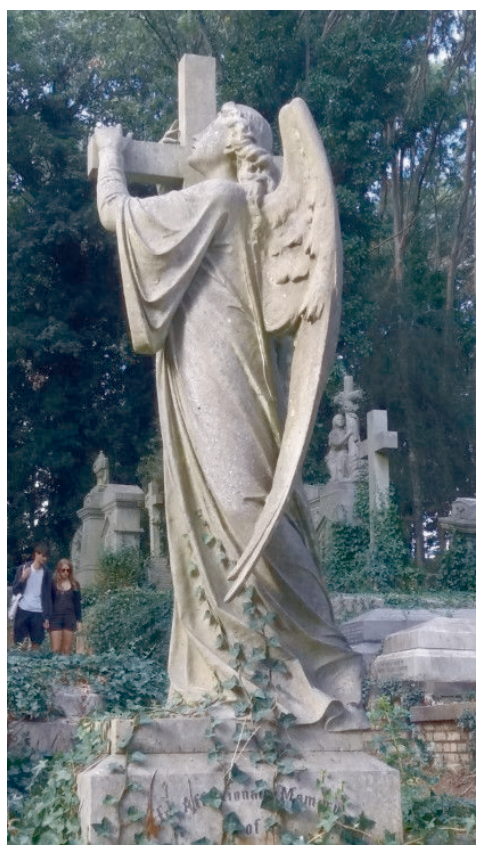

Fig. 9: There are several angel figures at Highgate Cemetery that lean on a cross, head lifted up towards heaven as if they would promise a better life beyond the human sphere. Highgate East Cemetery

(Image: Natalie Fritz 2016).

53 This is in other words, what Kierkegaard tries to illuminate by thinking about the qualities of repetition: «Repetition is the only reality and the sincerity of all existence. The one, who wants repetition has matured» (Kierkegaard 2000, 5, translation by the author). 
The tall, rather androgynous angel wears a long robe, like a burial gown, has long, slightly curly hair, holds a huge cross and looks heavenwards (fig. 9). The wings are half opened. It looks as if the angel's face has a melancholic expression. Is it longing for heaven? For redemption? That would mean hope. But does it look full of hope? The better existence after death seems to be a promise, but at the same time the angel embodies a specific form of pain, that affects the beholder. Maybe this feeling originates from the fact, that the angel holds a cross, in Christianity a symbol simultaneously of the greatest pain and of the joy of the resurrection. The cross in this case is a reference to Jesus -an arma Christi- and his sacrifice and is therefore linked to a specific conception of the afterlife, a Christian conception that was prevalent during a particular period - notably the Victorian age. ${ }^{54}$

The angel with the cross could thus be read as a means to transform or convey the deceased's or the bereaved's hopes for forgiveness and overcoming death into a material dimension. Because the inscription was overgrown with ivy, one could only read the head of the epigraph «In affectionate Memory». Thus one could assume that, during his or her life time, the person was willing to bear his/her burden', lived a pious life and at the end will gain admission to heaven. Maybe one could read the angel's shape as female - due to the artistic vogue at the time the tombstone was constructed. But in fact, for our exploration it is not of great importance, we will concentrate instead on the effect the angel representation has on our perception. The pain one feels watching the angel may be a reference to the deceased person moving on and leaving his or her beloved ones behind: a temporal sadness with a prospect of solace. For the bereaved this would imply that even though one mourns, faith in a good afterlife provides the living with a glimpse of hope and eventually comfort. In this case, Kierkegaard's thesis would seem absolutely logical: by repeating ritually (visiting the cemetery) the act of remembrance in the present, the bereaved transfer the past event of death into the present and transcend it into a state of prospective hope.

Or, maybe because of the lack of a name and the time span between us and the deceased, as contemporary visitors without any personal connection to the buried persons in the cemetery, we perceive this sort of angel as a mere representation of the hopes and concepts of the society the deceased person and the bereaved lived in: a society that was informed by

54 For more information about the meaning and memory function of the arma Christi see Cooper/Denny-Brown 2016. 
Christian faith and its idea of an afterlife, in which death was not an end of life but a new beginning. In this case, the angel figure serves more as a validation of common concepts and of the bereaved as part of this society. The huge angel on the grave would in this sense be more of a public memento mori than a personalised statue for a particular person. The angel would, to refer to Assmann, work as a material archive of a specific world view and thus would keep the contemporary visitors at a distinctive distance from the deceased person.

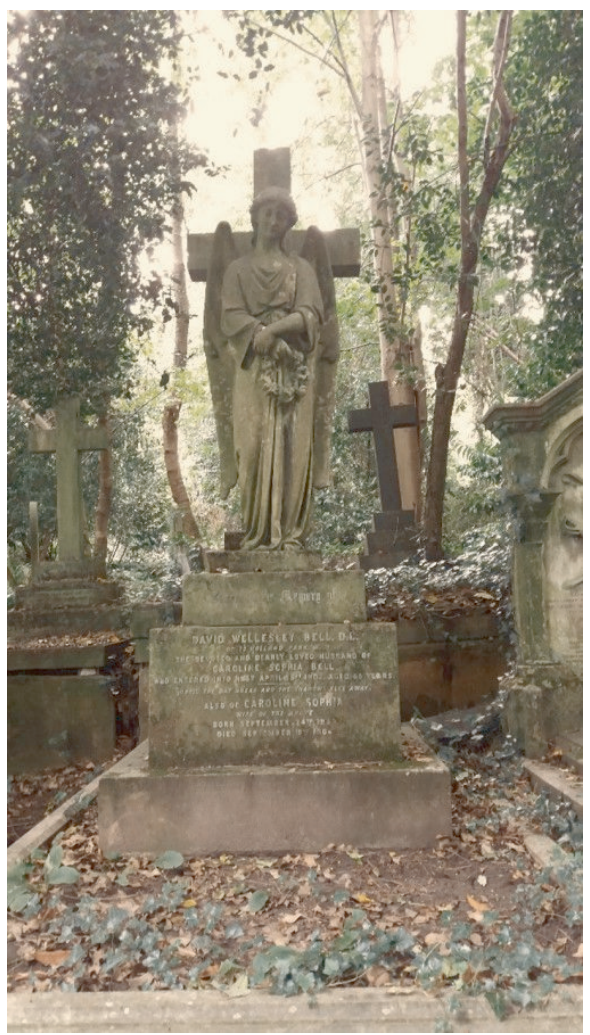

Fig. 10: The angel on the grave of the Wellesley Bell Family stands in front of a cross, holds a floral wreath in her hands and looks softly on the last resting-place of the family members. Highgate East Cemetery (Image: Natalie Fritz 2016).

Walking along the paths of Highgate other angelic sculptures come into view. There are angels that watch over the deceased persons with slightly 
inclined heads, holding floral wreaths or garlands (figs. 10 and 11). These ¿flower angels> function as messengers between the dead and the living, the past and the future, the individual and the public.

The angel on the grave of the couple Wellesly Bell (fig. 10) stands in front of a cross and looks mildly absent-minded but serious, as if she was contemplating or praying. Meanwhile she holds a floral wreath in her hands. It is a female-featured angel with long wavy hair and a long robe that reminds one vaguely of night gowns or Greek and Roman togas. The blossoms in the wreath resemble forget-me-not, which would be an explicit cue to the visitor, not to forget the couple. The angel in this case substitutes for the bereaved and mourns for them and does not forget about the deceased. One could say that the angel symbolises the inner and individual process of remembering brought into the public sphere. To push this observation a little further, one may say that this kind of angel amongst others is a manifestation of Belting's ideas about how individual and collective images amalgamate, inform our societies and provide us with orientation. ${ }^{55}$

The angel's relaxed position could imply that even though remembering the loss is hard, the pain lessens with time and this knowledge may bring comfort. While remembering, the feeling of loss is still there but less painful, because the process brings back the deceased for a moment and this effect can reduce the loss a bit. The angel and the gravestone as a whole do not appear to be a melancholic memory engraved in stone, but rather have a comforting effect. The angel reassures the viewers that the deceased will not be forgotten - even if there are no members of the family left to mourn.

In a similar fashion the angel with the floral garland (fig. 11), who is scattering a flower - a stylised forget-me-not (myosotis) - looks concentrated but not sad. The comforting effect is the same as in figure 10. Even if no one who has known the deceased is alive anymore, the angel will continue to remember. These angel figures do not function as representations of the deceased persons. Instead, they function as substitutes for the bereaved and their duty of commemoration. Even though the individual, living memory is gone with the death of the last grieving family member, the memory is transferred to a material artefact and therefore no longer a living but a saved memory. The angel figure serves in this case as a form of archive. ${ }^{56}$

55 See Belting 1998.

56 See Assmann 2006b, 186-190. 


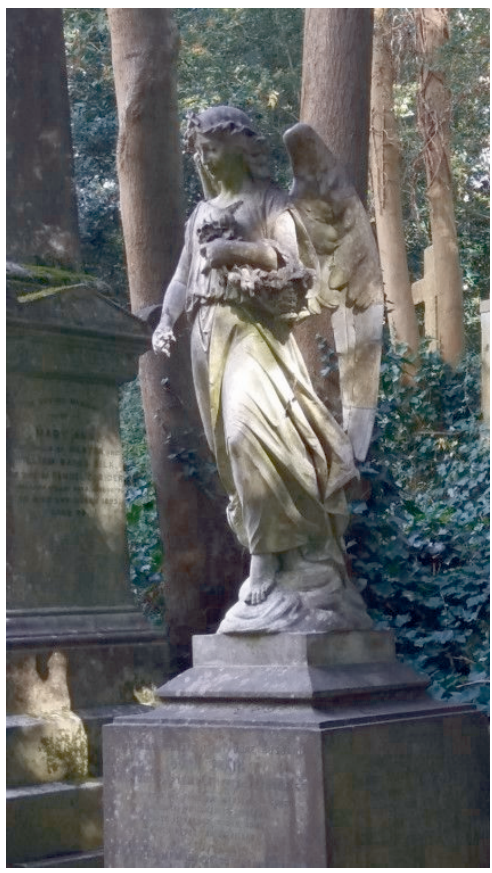

Fig. 11: This angel is scattering a forget-me-not, an explicit cue to the visitor. Highgate East Cemetery (Image: Natalie Fritz 2016).

6. Tell Me What Angel Decorates Your Grave and I Tell You, Who You Were. A Short Summary

Due to space constraints we have only been able to explore a selection of the various types of angel representations in Highgate Cemetery. Nevertheless, we have realised that each of the angel types considered have specific qualities and affect us in different ways. Angels functioning as or positioned on mourning monuments were once in vogue (especially in the $18^{\text {th }}$ and $19^{\text {th }}$ century, when a certain romantic attraction to death was prevalent), then their popularity lessened until they returned as puttos (cherubs) and in more modern designs and smaller scale. This underlines the fact that individual and collective image repertoires, and the resulting attributed meaning of images, change over the years depending upon the values and rules a society is based on.

The more personalised the angels are - with additional epitaphs or characteristic visual references - the more interested we become in the fate of 
the deceased persons and their families. It may even tempt us to reconstruct a family history of completely unknown people, just because we feel emotionally touched. The angel figure in these cases may be read as a visual representation of a specific benevolent characteristic of the deceased person, which the bereaved family wanted to highlight for the public and later generations as in figure 1 . Or, one could interpret the slightly spersonalised angel with its heart shaped wings embracing its body, as a symbol of deep affection beyond death, as in figure 8. Also, the recumbent angel in figures 6 and 7 works on an emotional level and visually underlines grief and sorrow. But, as in figure 1, it also works as a strong symbol of hope, because it is connected to a specific religious worldview that promises the good in the afterlife. This is also the function of the more popular angel representations we described. They represent a particular religious tradition as in figure 9, which comforts the bereaved and at the same time works as a visual archive of a specific moment during the process of religious transmission. In addition to this function, the angels in figures 10 and 11 visualise and make explicit the function of a tombstone - they show the visitors that even when no one who knew the deceased person is alive anymore, the tomb with its remembering angels will outlast and encourage the future visitors to read the epitaphs and in this sense revitalise the memory of the dead.

To summarise, one could say that angel representations in some periods were more common than in others. In Highgate we have a huge quantity of tombs from the Victorian age adorned with angels. Many of these angels look the same and tend to represent a specific religious worldview - a specifically Christian perspective - that was dominant in this precise period more so than a specific person or a quality of the deceased. They are for today's visitors sculpted archives of previous forms of a religious worldview and societies and also of past aesthetic sensibilities. As a consequence we could say that we, as contemporary beholders, perceive these tombstones at a certain distance. They are more artefacts than references to real persons. But, the more personalised exceptions are eye catching - as we experience stronger emotional connections looking at figures 6 and 7 or at the Beer Mausoleum. ${ }^{57}$ These angel representations communicate strong emotions beyond religious, cultural or temporal boundaries. And we could suggest that it is mostly due to their human shaped appearance expressing pain or comfort with which we as humans are perfectly able to

57 For a $360^{\circ}$ panoramic view of the Beer Mausoleum see https://highgatecemetery.o rg/images/tour/julius-beer-mausoleum/vtour/tour.html (accessed April 10, 2018). 
empathise. Even though they represent a specific religious tradition, the affective potential is striking even for today's visitors. There is no distance anymore, the overwhelming feeling of loss and grief is almost tangible all because an individual expression has been given to the angel figure and because a personal inscription accompanies it.

One can find modern adaptations of angels on tombs in Highgate, but they are not as popular anymore. Nevertheless, they either work as symbols of a specific afterlife - the angel as carrier of the soul - or express a particular feeling through their posture as in figure 8. As revitalisations of 〈older angel representations, they additionally transmit a tradition of representations connected to grief and loss as well as hope.

The polysemy of the angel as a religious symbol becomes obvious in Highgate Cemetery because of the different representations we are confronted with and which evoke diverse reactions in every single visitor. The setting in a public space, a cemetery, alongside other mourning monuments reinforces the polysemous aspect, because it also shows how visual conventions and ideals may change over the years and with this process new meaning can be created. The abundance of angel representations in Highgate Cemetery contains an immense reservoir of knowledge about religious traditions, cultural and social behaviour and power. Thus, we could conclude that the popularity of angels as grave adornment is on the one hand due to their polysemy and the emotional reactions their anthropomorphic representations may provoke in the beholder. On the other hand, it may also be due to the fact that even though these angels are made of stone, they can be read as a figurative connection with a transcendent sphere, which the beholder may experience her-/himself while remembering the deceased, death or life in general.

\section{Bibliography}

Assmann Aleida, 2010, Erinnerungsräume: Formen und Wandlungen des kulturellen Gedächtnisses, München: C.H. Beck.

Assmann, Aleida, 2006a, Soziales und kulturelles Gedächtnis. Vortrag im Rahmen eines internationalen Symposiums in Berlin 2006, 2. http://www.bpb.de/system/ files/pdf/0FW1JZ.pdf (accessed November 10, 2018).

Assmann, Aleida, 2006b, Einführung in die Kulturwissenschaft. Grundbegriffe, Themen, Fragestellungen, Berlin: Erich Schmidt.

Assmann, Jan, 1992, Das kulturelle Gedächtnis. Schrift, Erinnerung und politische Identität in den frühen Hochkulturen, München: C. H. Beck. 
Auerbach, Nina, 1982, Woman and the Demon: The Life of a Victorian Myth, Cambridge, Massachusetts/London: Harvard University Press.

Belting, Hans, 1990, Bild und Kult. Eine Geschichte des Bildes vor dem Zeitalter der Kunst, München: C.H. Beck.

Belting, Hans, 1998, Der Ort der Bilder, in: Belting, Hans/Haustein, Lydia (eds.), Das Erbe der Bilder, München: C. H. Beck, 34-54.

Belting, Hans, 2001, Bild-Anthropologie. Entwürfe für eine Bildwissenschaft, München: Fink.

Belting, Hans, 2005, Das echte Bild. Bildfragen als Glaubensfragen, München: C.H. Beck.

Berek, Matthias, 2009, Kollektives Gedächtnis und die gesellschaftliche Konstruktion der Wirklichkeit. Eine Theorie der Erinnerungskulturen, Wiesbaden: Harrassowitz.

Böcher, Otto, 1982, Engel. IV Neues Testament, in: Balz, Horst Robert et. al., TRE. Theologische Realenzyklopädie, Band 9, Berlin/New York: Walter de Gruyter, 596.

Böcher, Otto, 1982, Engel V, in: Balz, et. al., TRE. Theologische Realenzyklopädie, Band 9, Berlin/New York: de Gruyter, 599.

Boehm, Gottfried, 2010, Zuwachs an Sein. Hermeneutische Reflexion und bildende Kunst, in: Boehm, Gottfried, Wie die Bilder Sinn erzeugen: Die Macht des Zeigens, Berlin: Berlin University Press, 243-267.

Boehm, Gottfried, 2007, Die ikonische Figuration, in: Boehm, Gottfried/Brandstetter, Gabriele/ Müller, Achatz von (eds.), Figur und Figuration. Studien zur Wahrnehmung und Wissen München: Fink, 33-55.

Boehm, Gottfried, 1994, Was ist ein Bild, München: Fink.

Bredekamp, Horst, 2010, Theorie des Bildakts, Frankfurt a. M.: Suhrkamp.

Brown, Callum G., 2001, The Death of Christian Britain. Understanding Secularization 1800-2000, London/New York: Routledge.

Cooper, Lisa H./Denny-Brown, Andrea (eds.), 2016, The Arma Christi in Medieval and Early Modern Material Culture, Abingdon/New York: Routledge.

De Girolami Cheney, Liana, 1992, The Fair Lady and the Virgin in Pre-Raphaelite Art. The Evolution of Societal Myth, in: De Girolami Cheney, Liana, PreRaphaelitism and Medievalism in the Arts, Lewinston/Queenston/Lampeter: Edwin Mellen Press, 241-281.

Didi-Huberman, Georges, 2000, Vor einem Bild, München: Hanser.

Didi-Huberman, Georges, 1999, Was wir sehen blickt uns an. Zur Metapsychologie des Bildes, München: Fink.

Diers, Michael, 2009, Atlas und Mnemosyne. Von der Praxis der Bildtheorie bei Aby Warburg, in: Sachs-Hombach, Klaus (ed.), Bildtheorien. Anthropologische und kulturelle Grundlagen des Visualistic Turn, Frankfurt a. M.: Suhrkamp, 181-213.

Frank, Gustav/Lange, Barbara, 2010, Einführung in die Bildwissenschaft. Bilder in der visuellen Kultur, Darmstadt: Wissenschaftliche Buchgesellschaft, 47-52. 
Fritz, Natalie, 2018, Von Rabenvätern und Übermüttern, Das religionshistorische Motiv der Heiligen Familie im Spannungsfeld zwischen Religion, Kunst und Film, Religion, Film und Medien 3, Marburg: Schüren.

Fritz, Natalie/Höpflinger, Anna-Katharina/Knauss, Stefanie/Mäder, Marie-Therese/ Pezzoli-Olgiati, Daria, 2018, Sichtbare Religion. Eine Einführung in die Religionswissenschaft, Berlin: De Gruyter, 193-214.

Garrett, Gregg, 2015, Entertaining Judgement. The Afterlife in Popular Imagination, Oxford: Oxford University Press.

Geertz, Clifford, 1987, Dichte Beschreibung. Beiträge zum Verstehen kultureller Systeme, Frankfurt a. M.: Suhrkamp.

Gennep, Arnold van, 2004, The Rites of Passage, London: Routledge.

Gombrich, Ernst Hans, 1992, Aby Warburg: eine intellektuelle Biographie, Europäische Bibliothek, 12, Hamburg: Europäische Verlagsanstalt.

Halbwachs, Maurice, 1997, La mémoire collective, Maurice Halbwachs; éd. critique établie par Gérard Namer; prép. avec la collab. de Marie Jaisson, Bibliothèque de "L'Évolution de l'Humanité», 28, Paris: Michel.

Jones, David Albert, 2010, Angels: A History, Oxford: Oxford University Press.

Kierkegaard, Søren, 2000, Die Wiederholung, Überarb. und hg. von Hans Rochol, Hamburg: Meiner.

Kluge, Friedrich, 2011, Engel, in: Etymologisches Wörterbuch der Deutschen Sprache, Berlin: De Gruyter.

Krauss Heinrich, 2005, Engel. Überlieferung, Gestalt, Deutung, C.H. Beck, München.

Lutchmansingh, Larry D., 1989, Fantasy and Arrested Desire in Edward BurneJones's Briar-Rose Series, in: Pointon, Marcia R. (ed.), Pre-Raphaelites ReViewed, Manchester/New York: Manchester University Press.

Mendelssohn, Henriette, 2012 (1907), Die Engel in der bildenden Kunst. Ein Beitrag zur Kunstgeschichte in der Gotik und der Renaissance, Barsingshausen: Unikum, 79.

Osten, Gert von der, Engelpietà, in: Reallexikon zur Deutschen Kunstgeschichte, Bd. V (1960), Sp. 601-621; in: RDK Labor, http://www.rdklabor.de/w/?oldid=93200 (accessed July 13, 2017).

Pezzoli-Olgiati, Daria, 2008, Film und Religion. Blick auf Kommunikationssysteme und ihre vielfältigen Wechselwirkungen, in: Nehring, Andreas/Valentin, Joachim (eds.), Religious Turn -Turning Religions. Veränderte kulturelle Diskurse-Neue religiöse Wissensformen, ReligionsKulturen, Bd. 1, Stuttgart: Kohlhammer, 45-66.

Pseudo-Dyonisus, 1987, The Complete Works, translated by Colm Luibheid and Paul Rorem, New York: Paulist Press.

Schade, Sigrid/Wenk, Silke, 2011, Studien zur visuellen Kultur. Einführung in eine transdisziplinäres Forschungsfeld, Bielefeld: transcript. 
Schmidt, Heinrich/Schmidt, Margarethe, 2007, Die vergessene Bildersprache christlicher Kunst: Ein Führer zum Verständnis der Tier-, Engel- und Mariensymbolik, München: C. H. Beck.

Stolz, Fritz, 2001, Grundzüge der Religionswissenschaft, Göttingen: Vandenhoek \& Ruprecht.

Turner, Victor, 1995, The Ritual Process. Structure and Anti-structure, New York: Aldine and de Gruyter.

Waldenfels, Bernhard, 1990, Das Rätsel der Sichtbarkeit. Phänomenologische Betrachtungen im Hinblick auf den Status der modernen Malerei, in: Waldenfels, Bernhard, Der Stachel des Fremden, Frankfurt a. M.; Suhrkamp, 204-224.

Wuttke, Dieter, 1998, Aby M. Warburg-Bibliographie, 1866 bis 1995: Werk und Wirkung, Bibliotheca bibliographica Aureliana, 163, Baden-Baden: Koerner. 